\title{
Accessing the Research Community: Metaphors in Understanding the Processes of Becoming a Researcher
}

\author{
Tuure Tammi and Anna Kouhia \\ Department of Teacher Education, University of Helsinki, Finland
}

\author{
tuure.tammi@helsinki.fi; anna.kouhia@helsinki.fi
}

\begin{abstract}
This article examines the questions of professional identity formulation and the possibilities of young scholars to reflect on these processes. Relying on insights of collaborative autoethnography, this article is based on a four year long process of exploring our ways of participating in the community of academic practice. This process is studied through discussing various metaphors related to academic life. In this article, metaphors are used as methodological tools to characterize and reflect on young scholars' being and becoming in the academic world. First, we consider how different metaphors may help us to communicate with others, and then continue reflecting on the acquisition and participation in the communities within which we become scholars. Finally, we elaborate on two metaphors - methodological mess and endless scholarly immaturity - to navigate in the research community as (young) researchers.
\end{abstract}

Keywords: professional identity, metaphors, collaborative autoethnography, participation, young researchers, doctoral students

\section{Introduction}

In finding their professional identity and place in the field of academic research, many young researchers struggle with questions relating to professional life and academic calling: Is what I do worthwhile? Am I able to succeed in my work? Am I on the right path? (Hakala, 2009, p.178). In this article, we apply a practice-theoretical understanding on development of professional identity. According to this view, professional identity can be considered as a relation between the emerging understandings of oneself and the means, goals, and motives (or justifications) of the practical activity (Räsänen \& Korpiaho, 2011). Identity is thus understood as a process in which the subject becomes engaged with and aware of the practices and ideas valued by the community in question and gains competence through participating in these practices (Lave \& Wenger,

1991). During that process, the partici-

Material published as part of this publication, either on-line or in print, is copyrighted by the Informing Science Institute. Permission to make digital or paper copy of part or all of these works for personal or classroom use is granted without fee provided that the copies are not made or distributed for profit or commercial advantage AND that copies 1) bear this notice in full and 2) give the full citation on the first page. It is permissible to abstract these works so long as credit is given. To copy in all other cases or to republish or to post on a server or to redistribute to lists requires specific permission and payment of a fee. Contact Publisher@InformingScience.org to request redistribution permission. pants continuously renegotiate different meanings and sets of relations in the community, increase their participation and, according to Lave and Wenger (1991), move from the periphery to the center, also gaining more power and prestige within the communities. This perspective situates the learning of doctoral student within the scholarly community. 
Recent scholarship has noticed that the problems doctoral students face in their doctoral processes often stem from the relation between student and research community (Räsänen \& Korpiaho, 2011; Vekkaila, Pyhältö, \& Lonka, 2013). Doctoral students' experiences of their own doctoral processes, in particular, have been shown to contribute to students' well-being and satisfaction, thus increasing their perceived fit into academic communities (Pyhältö, Vekkaila, \& Keskinen, 2012). As doctoral students, we have found it extremely important, yet difficult, to reflect on our processes of becoming members of scholarly community. In this article, we aim to find tools to tackle with this issue. In particular, we explore whether thinking with metaphors could offer some help in positioning oneself in the research field, finding one's place in the community, and understanding oneself as an emerging researcher. We thus take our current position as "emerging scholars" as a possibility to make sense about the community of practice through which our scholarly identities are being produced. Even though learning is sometimes described in terms of a move from periphery to the center, the mastery in the community of practice is not regarded as fixed, but as evolving, changing, shared, sustained, and even struggled by its members (Lave \& Wenger, 1991). We emphasize that the communities in question are also situated within broader (e.g., economical) settings and have to adjust to these constraints in varying degrees.

In composing the article, we have engaged in the practice of writing through a collaborative autoethnographic approach as we have tried to understand construction of academic identities through metaphors. Thus, we use metaphors in order to think about our processes of becoming and the contexts of this becoming. We approach these issues from standpoint of doctoral students in the Faculty of Behavioral Sciences in the University of Helsinki. As doctoral students, we are academic rookies taking our first steps as researchers; besides, we are fellows in our early thirties, both trying to balance between professional career and family life in our own ways. As our investigation on metaphors proceeds, we will reflect on our positions closer, and situate ourselves further within the fields of science politics, disciplinary ideals, and everyday of scholarly practice. Thus, we will consider metaphors as methodological tools to study possibilities and constraints of the academic world on micro, meso, and macro levels. We further explore two metaphors on learning presented by Sfard (1998) that may help us to understand the learning involved in the process of accessing the worlds of research. Finally, we will introduce two metaphors of our own - methodological mess and endless scholarly immaturity - that cast light on our becomings as young researchers within the landscapes of academia. Through thinking with these metaphors, we also connect to a postmodern view on professional identities as navigation among different forces. We perceive that the ideas presented in this article - especially regarding the selfreflective method of thinking with metaphors - could potentially offer tools for other young researchers, as well as their supervisors in this regard. We consider thinking with metaphors as an intellectual quest.

The paper proceeds as follows. First, we will formulate a theoretical understanding on metaphors. Second, we will consider the methodological underpinnings of autoethnography and collaborative writing, after which we will reflect on our experiences as emerging scholars with the help of various metaphors. Finally, we will consider certain metaphors as "methodological tools" for formulating understanding of our becomings as researchers. At the same time, we produce analysis of the contemporary academe from a perspective of young researcher.

\section{Metaphor and Its Uses}

Metaphor as a cognitive conception reflects the human ability to connect different domains based on experiential connections (Sweetser \& Fauconnier, 1996). The operative word here is "connections," since by the use of metaphors, as Sweetser and Fauconnier (1996) note, understanding of one domain in terms of another is evoked. For Sfard (1998, p.4), the power of metaphor lies in this act of conceptual bridging: forging connections between the competing intuitive and formal 
outlooks, metaphors can spontaneously link experiences of everyday reality to scientific theories. In other words, metaphors offer an understandable form for abstruse ideas. Sfard $(1998$, p.5) further argues that explaining the processes that turn old into new metaphorical figures of speech allow researchers to nominate what is perceived unfamiliar, to step from one domain to another using language. Still, metaphorical entailment that tends to migrate across domains often remains unnoticed and uncontrolled (Sfard, 1998).

Many people consider metaphors as devices of the poetic imagination and rhetorical flourish or as matters of characteristic language that combine concept structures to thought and action (Lakoff \& Johnson, 1980). Relating dissimilar ideas to establish a comparison, metaphors, in fact, are far from being mere rhetoric. Moreover, metaphors have essential influences on how important societal issues and everyday experiences are conceived and conceptualized (Lakoff \& Johnson 1980; Thibodeau \& Boroditsky, 2011). Although metaphors that are used to reason about concepts may be inconsistent, Lakoff and Johnson (1980, p.272-273) see that abstract concepts are not complete without metaphors. As they (1980, p.273) summarize, "We live our lives on the basis of inferences we derive via metaphor." In this article, we aim to emphasize the role of metaphors as conceptual bridges that connect discourses to everyday life, or nominate the unfamiliar.

In recent research literature, metaphors are often characterized by their figurative language or context. For example, in cognitive science, Beaty and Silva (2012) distinguish between conventional and creative metaphors. Conventional metaphors are perceived as straightforward or idiomatic expressions that often represent a comprehensible comparison between a topic and a characteristic exemplar, while creative metaphors are unique, fresh expressions that use transient association to describe an emotional experience or express imagery in everyday speech. Conventional metaphors are rather familiar and easy to comprehend, such as the one-to-one in comparison, "life is a journey" or "time is money." Creative metaphors are inventive and unforeseen, often emotionally charged uses of language; neither the creator nor the audience have encountered the metaphor before (Beaty \& Silva, 2012). These more complex metaphors require more explanation and clarification, as we will see later on when discussing our metaphors of "endless scholarly immaturity" and "methodological mess". This division to spontaneous and nonspontaneous types of metaphors supports the idea that metaphors in written language often tend to be more or less carefully considered and meticulously formulated' and therefore defined by conventional attributes, whereas in speech metaphors flourish in spontaneous expressions. While creative metaphors may act as unplanned expressions in everyday life, conventional metaphors offer us ways to conceptualize ideas by making interpretations that reflect broader social-cultural horizons. Moreover, different ways of interpreting metaphors are tied to individual culture and history, and thus shared in social contexts (Lakoff \& Johnson, 1980). For example, understanding of the metaphor "time is money" requires that both "money" and "time" exist culturally and in relation.

In short, metaphors act as conceptual bridges that can help us to communicate with others and understand, so far as it is perceived, the world in which we live. However, the use of metaphors is highly consequential and it depends upon personal life histories and social contexts (and the discourses permitted within these contexts). In this article, reflecting on the academic community that we as young researchers are accessing, we use metaphors as methodological tools to develop new understandings of our ways of "becoming".

\section{Methodological Considerations}

A commonplace way of considering one's doctoral journey is to reflect on the shift from a doctoral student to an academic scholar. Many studies, often written retrospectively from the years of distance and from the higher-ranked positions (e.g., Gallos, 1996; Hernández, Sancho, Creus, \& Montané, 2010), report how “becoming a researcher" raises questions of one's identity, or how 
young academics understand themselves within the social climate of their universities. In the present article, we are interested in the same questions; we, however, approach the questions autoethnographically as "emerging scholars" from the periphery of the academia (see Lave \& Wenger, 1991). We are especially interested in what certain metaphors evoke in us, most of which are generated by others, from a certain academic point of view, in certain time that may be different from that of ours.

Considering the metaphor as a methodological tool, the present article includes aspects from the autoethnographic research approach, as the "data" we rely on consists to a great degree of retroactive writings about our experiences. We use the autoethnographic research strategy to systematically describe and analyze (graphy) our personal experiences (auto) in order to understand the culture around us (ethno) (Ellis, 2004; Ellis, Adams, \& Bochner, 2012). According to Ellis (2004, p. xvii), the aim of autoethnographic writing is to "enter and document the moment-to-moment, concrete details of life", and use one's experiences to find meaningfulness with a larger group or culture. While the things that are encountered through autoethnographic introspection may not always be flattering, or they might even generate emotional pain, autoethnography seeks to make lived experiences visible through honest exploration (Ellis, 2004, p. xviii). This, further, requires researchers to identify the disciplinary ground on which they stand, question and reflect on their decisions and motives, and acknowledge the limitations of their own voice with which they speak (Dauphinee, 2010; Ellis 2007). For us, autoethnographic research approach has provided a practice-theoretical framework for reviewing the domains of practice we have undertaken as doctoral students. This means that while trying to understand ourselves, we have been conducting "a systematic sociological introspection" (Ellis, 2004, p. xvii) of the practices of our academic community from the position of doctoral students.

Lately, collaborative autoethnographic projects, in which researchers pool their experiences to discover the correspondence and divergence of the meanings of the life experiences in relation to the sociocultural contexts, have been starting to flourish alongside the works of solo authors, thus proposing an emerging collaborative research framework combining autobiographical, dialogic, and ethnographic writing (Chang, Ngunjiri, \& Hernandez, 2012). While in some projects, researchers have chosen to collaborate concurrently throughout the study (e.g., Chang, Ngunjiri, \& Hernandez, 2010), other projects have placed more emphasis on the dynamics between the self and other, engaging researchers who have worked individually at certain stages of research and collaborated in others (e.g., Hernandez, Ngunjiri, \& Chang, 2014). During the writing of this article, we have been collaborating at all stages of research: We have been sharing ideas, reading and writing, detailing and documenting the academic practices, developing the metaphors in and through our discussions, and engaging in collective analysis and interpretation. In order to intentionally embed our reflection in the socio-cultural environments within which we become scholars, we have further shared our thoughts with our colleagues and become inspired (or sometimes depressed) from these discussions that have circled around our emerging scholarship.

Writing autoethnography collaboratively has prompted us to share the ideas of Chang, Ngunjiri and Hernandez (2010), who have claimed that the strength of the collaborative autoethnography is that it enables an open, context-conscious perspective of the personally embodied experiences with an emotional and cognitive resonance to the experiences of the others. Nevertheless, the underlying dilemmas of the autoethnographic writing, such as telling the stories subjectively in content and context (see Ellis, 2007), or the power and privilege of the academic voice (see Dauphinee, 2010) remain in collaborative autoethnography. Therefore, it needs to be acknowledged that in the course of writing and representation we are unable to withhold the all-encompassing academic voice: While detailing our experiences of accessing the academia, we already operate with, and take the use of, the set of conventions, concepts and practices within the academia. For example, when writing this article, we may contribute to the world of academic rankings (a prac- 
tice based on certain ideological premises) through article publishing - a world, the complexity of which has only recently began to manifest to us. Similarly, we are on our way to "becoming" insiders or full participants as we become involved, achieve new understandings, and eventually incorporate the scholarly profession as part of our identities.

We have both started our doctoral studies in the field of Behavioral Sciences working outside academia: Anna as an educator in the field of arts and crafts, and Tuure as an elementary school teacher. We came across each other in the early phase of our doctoral journeys within an organizational doctoral study project in 2011, where we both worked as project researchers. Anna has also worked on a scholarship for a year. Since then, we have both been employed by the university, which has provided us a fulltime doctoral student position at the Department of Teacher Education. Our academic paths are not identical, but they have much in common. We have shared much throughout the years, and much has become shared during our collaborative autoethnographic projects.

Data production for the project examining the development of professional identity began in 2012, when we two started to meet regularly in order to discuss our experiences in academia. What are we doing here and why? We read articles for every meeting and wrote down our ideas together. These "data" (meetings, writings, readings) were recurrently enriched through meetings with our colleagues. In particular, one summer school gathering together of young researchers from European countries to discuss methodological issues in 2012 was of great importance for the development of the ideas of this article. As we discussed our experiences of the development of scholarly identity, concerns about disfigurement of the academic world and imperfection of the scholarly competence seemed to be widely shared by all of us summer school participants. Thus, while the metaphors presented in this article cannot be generalized to broader population, and we are not even attempting to do that here as we are experimenting with postmodern techniques of autoethnography, we perceive them as reflections on our deepening engagement to the academia, complementary to the experiences other people sharing our position. However, whether one agrees with the metaphors introduced here or not, is not the core issue in the article. What we attempt to do is to introduce one possible "method" for self-reflection as we think such reflectivity is essential for any emerging scholar.

\section{Gaining Access through Acquisition and Participation}

At the beginning of one workshop at the abovementioned summer school we both attended in 2012, we were presented with Francis Bacon's (1620/1863) Aphorism XCV; a metaphor of ants, spiders, and bees from his book Novum Organum:

Those who have handled sciences have been either men of experiment or men of
dogmas. The men of experiment are like the ant, they only collect and use; the
reasoners resemble spiders, who make cobwebs out of their own substance. But
the bee takes a middle course: it gathers its material from the flowers of the gar-
den and of the field, but transforms and digests it by a power of its own."

The excerpt was used as a pedagogical tool to encourage us to think about our identities as researchers by asking which one of the described insects could best represent us. However, we, among other participants, found the task of naming oneself as a certain kind of researcher rather difficult. Nearly all young researchers who participated in the discussion felt having some of the characteristics of ants, spiders, and bees alike. Naming oneself as an ant, a spider, or a bee was causing frustration among the participants, as if "the scholarly antness" would mean that one was only capable of conducting uninventive research, or "the spiderness" that one was only willing to work by one's own rules, or "the beeness" that one was to become a scholars of masses lacking both vision and originality. It was clear that the participants wanted to emphasize the social and 
cultural nature of being and becoming a researcher. As a solution to the problem, both various hybrids (e.g., spider-bees) and other species (e.g., butterfly) were suggested. Some participants reasoned that even though one might have acquired, say, bee-like strategies, s/he has done so in a certain context of power and privilege, within a community valuing certain attributes and being subjected to certain broader powers. Thus, in understanding the formulation of identity, we figured, we must not only look at what we possess (the concepts, tools, ideas), but also the contexts in which these are recognized.

This idea is well articulated by Sfard (1998). According to her, the metaphors of acquisition and participation can be thought to form a contradictory, yet interwoven dyad thus pointing out the complexity of defining learning. The metaphor of acquisition includes an idea of the "human mind as a container to be filled with certain materials and about the learner as becoming an owner of these materials" (Sfard, 1998, p.5). From the viewpoint of acquisition, learning is a means for the acquisition and accumulation of new knowledge, new information, ideas, or conceptions: a process of gradually gaining ownership over what is constructed, attained and internalized. Once acquired, new conceptions may be applied, articulated, and shared with others, and this "property" can thus be employed in a great variety of frameworks. The idea of acquisition has shifted over time from the passive reception of knowledge to the transformation of knowledge from a social to an individual plane, now putting more emphasis on the active role of the learner (Sfard, 1998, p.5-6). As Sfard (1998) observes, this metaphor works only partly. In 2013 we wrote about our processes as young researchers in the following way:

"Almost daily, we need to think whether we use certain scientific tools in the right way. We feel that we are expected to use the accepted tools of good scientific practice [...] but on the other hand, we are participating in negotiating these means through developing analytic procedures that help us to approach the data."

Whereas acquisition mostly concentrates on possession and state, the metaphor of participation gives priority to activity and agency; instead of different "concepts" and "knowledge" it focuses on "knowing" as active doing (Sfrad, 1998). When contrasted with the metaphor of acquisition, the participation metaphor, according to Sfard $(1998, p .6)$ is a context-related, open-ended body that emphasizes situatedness, cultural embeddedness, and social mediation: learning is then perceived as a "process of becoming a member of certain community." In the qualitative inquiry the analytical methods seem to be open to improvisation and experimentation. The methods we use (or "own") and the ways we use them define our appearance to others and, thus, our emerging professional identity. The difficulty here is that the community of qualitative researchers is diverse as well: authoethnography, for example, is not perceived as valid or trustworthy scientific method in all academic fields. For example, our autoethnographic texts have been celebrated in certain scholarly communities and neglected in others.

According to Lave and Wenger (1991), we learn and gain memberships in the communities by taking part in the community practices. As doctoral students, we are learning to write articles, publish in high-ranked journals, present in conferences, and engage in scientific discussions. While we read, write, and engage in discussions with our colleagues, we also encounter new concepts through which we continue negotiating our being and becoming within the scholarly world. For example, issues of precarity and young scholars as members of precariat (e.g., Standing, 2011) have been recently discussed in our research community. In regard of the concept, we have been reflecting on the nature of academic work, sharing in length our experiences of undertaking a doctoral degree, and discussing the position of young academics as knowledge workers (see also Hakala, 2009) within the academia. Interestingly, the more we have talked about the metaphor of precarity - the insecure, relatively poorly paid, unprotected class of academic workersthe more we have realized the presence of the concept within our own academic lives. Thus, following Sfard (1998, p.6), we believe that we learn to negotiate meanings relating to the subject 
learned when we "acquire" new concepts or ideas: we learn how to act according to the particular norms and communicate in the language familiar to the community. Our acquisition of ideas and the use of these ideas is interwoven in the academic flows, and many times we don't have a possibility to refuse.

From a practice-theoretical point of view, becoming a member of a research community requires the scholar to acquire the conception of "good science" and participate in sustaining (and on the other hand challenging and developing) it with scientific choices. The scholar must both recognize that possession defines the identity of the possessor and, at same time, when contextualized the possessor is becoming a part of a greater entity (Sfard, 1998). It is believed that scholars do not become researchers in a vacuum, but someone (often old-timers of this community) has to grant access legitimately by approving the learner's application and symbolically approving his or her "potential". Moreover, researchers seem to need to acquire certain concepts in order to participate in meaningful activities (as numerous as these may be) and become more competent actors in the research community - to become perceived as legitimate scholars. It can be thought that scholars learn about which contents are most crucial to certain "tribes and territories" by this very participation.

\section{Tribes and Territories within the Triple-Helix}

Becher and Trowler (2001) offer conceptual tools for positioning in the academic world through their metaphor of "academic tribes and territories." In a cognitive realm, they separate hard from soft and pure from applied sciences. Hard sciences are quantitative and method-centered, knowledge is atomistic and cumulative, and they aim at causal explanation and ascertain universal laws. The criteria for good research are clear, as in the soft sciences, theories are multiple and the criteria for evaluation differ between schools and research orientations. In the soft sciences, research is usually qualitative and holistic. With the term "pure", Becher and Trowler (2001) refer to basic research that is directed from inside the university as applied sciences are directed from external needs. In the social realm, a distinction is made between convergent and divergent, and urban and rural disciplines. Convergent refers to strict rules and tightly bound disciplines as divergent disciplines are more fragmented. Urban fields are characterized by a fast and competitive group life, as its counterpart produces research slowly and as scholars have their own territories, less competition exists. These two realms and the four constituent parts of the realms offer a metaphor of "academic tribes and territories" that aims at explaining the organization of the university. Remarkably, however, Becher and Trowler (2001) also note that the attributions of the realms may change over time and space.

At first glance positioning ourselves as researchers in this metaphor seems easy. In our first discussions, we figured ourselves as representing soft (qualitative educational research), pure (research plans made by ourselves under the guidance of our professors), divergent (drawing from various fields and disciplines), and rural (emphasis on individual work in conducting research). Yet, we soon noticed that we could also find other kind of characteristics in our work. We memorized conversations with our supervisors and colleagues about the importance of learning to conduct both qualitative and quantitative research, attempts to productize our research in order to secure funding, and encouragement for publishing with our supervisors or other colleagues. Increased competition is continuously emphasized, and some publishing is valued more than others. Having said this, we have found that positioning ourselves in the tribes and territories is more complex than it seems: it is not merely accessing clearly bounded tribes with territories, but rather navigating between, inside and across them.

The metaphor of triple-helix will help us situate our working environment within some broader societal (and global) trends of higher education. Some argue that the old norms of science are falling away, being replaced with new, applied, competitive and entrepreneurial ones (e.g., 
Slaughter \& Leslie, 1997). The academic landscape has undergone major shifts during recent decades, and many universities have faced several reforms relating to their efficiency and accountability in Finland, but as well as in other countries (Becher \& Trowler, 2001; Hakala, 2009; Kouhia \& Tammi, 2014; Slaughter \& Leslie, 1997). In general, the function of the university has slowly changed from acting as an autonomous and unitary agent of basic research towards becoming a part of "a triple helix" (see Etzkowitz \& Leydesdorff, 1997), in which the tasks previously assigned to government (applied research) and industry (applied research and product development) are interwoven with those of academe (valid and valued science). As a result, this change in focus means that some universities are "becoming more involved in technology transfer, intellectual property, and the exploitation of knowledge" (Hemlin, Allwood, \& Martin, 2008, p. 202).

At first, the faculty of behavioral sciences seems an unlikely place to look for such entanglement with industry as in Finland the educational sector has mostly been run by public funds. However, we found that the entrepreneurial discourse had entered also our scholarly practices especially through changing practices of publishing. When we began thinking about post-graduate studies around 2009, doing a monograph was still considered an alternative. This, however, had more or less changed when we began our studies in 2011. We found most of our colleagues doing article based dissertation, many of them being engaged in various research or article writing projects outside their own work. After 2014, when doctoral education was reformed and unified in Finland, the steering document of the doctoral program to which both of us enroll has recognized only international peer-reviewed articles as legitimate foundations for a dissertation (see Kouhia \& Tammi, 2014). Partly this development can be interpreted to reflect on the increased measurement practices - part of the governmental funding for faculties is allocated on basis of the quantity of articles produced in different "quality categories", for example. Through article writing practices we also produce material for the growing science publication business. Paradoxically, while the research articles we produce are publicly funded, the articles we have written often need to be bought back by our (publicly funded) libraries in order to become available for our colleagues and students. Publishing (more and more) is presented to us among the only ways through which we can prepare ourselves for the uncertain future of the highly competed knowledge markets.

Thus, to a degree, we perceive that the dilemmas related to situating ourselves along with the tribes and territories reflect on the diversified functions of the university on a macro level. The metaphors of "triple helix" and "entrepreneurial university" are important especially for a new generation of researchers because they help us to understand the contemporary university in which we work and the altered demands and opportunities this suggests compared to those that many of our professors faced as young researchers. Of course, this set pressures to the supervisors as well: in which degree to adapt to the demands of knowledge economy and in which to give support to the alternative projects doctoral students might feel need to engage in.

Consequently, as we have found, "accessing the research community" can be approached as a complex activity, situated within a broader societal (and global) context, and comprised of the dynamic interplay of acquisition and participation within the landscapes of faculties, schools, departments, and research groups (i.e., tribes and territories), which positions our "being" and sets directions for our "becoming". Scholarly identity is not only up to scholars' own efforts, but is socially, culturally, and historically embedded. Acknowledging that "accessing" is surely a complex process, we want to take this complexity a little further. In following, we elaborate on two postmodern "creative metaphors" (Beaty \& Silva, 2012), which we created in order to reflect on our processes as young researchers who have just recently accessed the world of research. 


\section{Creating Metaphors for Understanding the Process of Accessing}

In the process of developing metaphors, we encountered the problem already addressed by Sfard (1998) that although similar concepts may be acquired, the meanings might differ. Let us take an illustration. Some months ago, Tuure had a debate with a colleague about the meaning of messiness. He had written a short paper titled "Messy agency" implying that agency is too often used as an unproblematized buzzword and scholars need to pay more attention to its use. Thus, messiness could be accepted as an encouraging concept, motivating the researcher to go beyond the trend and pushing him or her toward clarity. However, his colleague found the messiness to be discouraging. For her, messiness makes the task of clarity seem unreachable, pushing away the researcher. We talked about the same concept but the "sense" about the concept was different.

At first inspired by Sfard's (1998) metaphors, we have constructed new expressions that could enlighten the intermittent insufficiency that we as newcomers to the field of academic research have been experiencing. Thus, we elaborated our academic identities through the metaphors of "methodological mess" and "endless scholarly immaturity" that both accentuate that there is a number of underlying, still continuously evolving presumptions present at any given moment the research is conducted. Yet, these metaphors also maintain the idea that presumptions are fuelled by contextuality - they are entrenched in the researchers' mind (and cultural worlds), and so guide them in their work. These two metaphors emphasize the processual nature of becoming a researcher, yet situate this process in the changing socio-cultural patterns.

To all appearances, the main purpose of messiness is to challenge the metaphor of acquisition, as it seems that the concepts that have been acquired and internalized (such as agency, voice, culture, democracy) remain controversial in definition. It even seems that these concepts are contested in nature, open to ongoing questioning and elude definitive description. This discussion leads to the most profound questions concerning acquisition: To what extent is it possible to own these concepts that are repeatedly redefined? Participation in a community of research reveals the messiness included in the acquisition of concepts and meanings. Yet, these incomplete concepts are used in order to participate in scholarly discussions in publications. Thus, in the world of research (at least in the tradition of thought that is currently being accessed), researchers navigate in methodological mess in order to provide fresh and insightful reports, ideas, and theories.

While the metaphors of "methodological mess" and "endless scholarly immaturity" admit that researchers are strained to manage different motivations and interests, they underline the everpresent complexity in both scientific thinking and methodological contemplation. These metaphors certainly evoke anxiety - we can easily notice such frustration only by looking at the email conversations we have shared during the past years - but they also function as sources of curiosity. We have felt that messiness and immaturity may also advance our productive thought and help us to reconsider, deliberate, and tolerate paradoxes in ways of thinking and acting. For us, messiness is not something to be solved completely, but rather something that invites to navigation.

In the field of childhood studies, Gallacher and Gallagher (2008) have introduced a concept of "methodological immaturity" with which they criticize the current trend to blindly believe in participatory methods as a solution for the dilemmas in research with children. To them, research must be seen as an experimentation that requires methodological immaturity, as researchers are "not simply reporting a world that exists 'out-there,' but are creating and experimenting with an emergent one" (Gallacher \& Gallagher, 2008, p.511). They further promote an understanding where knowledge is relational and humans are emergent becomings: "always-unfinished subjectsin-the-making." 
The metaphor of "endless scholarly immaturity" shares the latter assumption. By developing this metaphor we have intended to pay attention to the infinite process, granting that endless scholarly immaturity does not eliminate the idea of transformation as scholars - only the "completeness" becomes insignificant. Nevertheless, we do not use immaturity as a metaphor for escaping the responsibilities for actions a scholar has engaged in during the research process. In contrast, as metaphor assigns incompleteness to every scholar, it also does so to every research project. If science were perfect, it would not be a mystery.

Although never perfect, we have experienced "moments of clarity" and "hints of maturity" during the processes of accessing. These incidents have been good analytical opportunities for us as reflexive researchers. In times of moments of clarity or hints of maturity, we have witnessed a temporal tolerance for uncertainty in ourselves, or even reached a confidence of some kind in that very moment (we might call this an identification). "Moments" and "hints" have often occurred in relation to something our colleague said about our study, something we just read, or an unexpected encounter at the café, for example. The momentary, fleeting experiences of clarity and maturity suggest that messiness and immaturity are never realms of total turmoil, and even while it sometimes may seem like it, our becoming is not mere postmodern chaos. We do notice some of our learning, we do get things done (e.g., this article), and we do develop skills and knowledge valued in the various communities of scholarship. Through focusing on the moments of clarity and hints of maturity, noting the moments when messiness and immaturity are interrupted, we may cast a new light on the processes of being and becoming a researcher in a specific time, place, and space. Still, it must be highlighted that moments of clarity and hints of maturity seem to depend on our situated processes of learning, and may thus be never guaranteed as outcomes of any learning process. Neither do these moments and hints seem to occur at regular intervals, but rather tend to accumulate in sequences that resonate with the learning processes. However, when looking at accessing (or participating in the communities of practices), it seems possible that as we learn, the moments of clarity and hints of maturity may become more frequent because of our growing involvement. We might learn to "master" our methods better, become better aware of the range of choices we have made during the research process, and begin more thoroughly acknowledge the effects that we and the other people encountered during the process of research may have had on the frame of the conducted research. In short, we might learn to navigate in the methodological mess with endless scholarly immaturity as our compass.

As has already been suggested, we consider that research is not only about individuals who study, but also about deeply interwoven social, cultural, and historical processes. This speaks for the contextuality of "methodological mess" and "endless scholarly immaturity" in both scientific thinking and methodological contemplation - the world changes and the new problems that arise might need new openings in this regard. In this vein, the metaphors lead us to a consideration of the construction of the academic communities and the strategies in navigating between the diversified forces that are faced while doing research.

\section{Navigating in the Methodological Mess with Endless Scholarly Immaturity as a Compass}

As Lave and Wenger (1991) suggest, we as newcomers to the community of practice are being pushed to find our ways through many burdensome challenges while wandering from the academic periphery to the core of the community. The challenges that currently concern us as researchers most relate to our academic identities and the processes of finding our place (and becoming "placed") in the community of researchers. We are not alone with our concerns; a comprehensive survey by Pyhältö et al. (2012) on Finnish doctoral students' perceived fit into academic communities suggests that doctoral students regard academic disengagement as a central challenge of their doctoral processes. In times like this when the number of $\mathrm{PhD}$ students is con- 
tinuously rising in many countries, as well as in Finland, and the competition for academic positions is increasing, finding "a place" is not an easy task (Hakala, 2009). For example, we have found very difficult to think where we will be five years from now. Utilizing our newly presented metaphors as strategies of coping with the challenges, we could say that using scholarly immaturity as our compass, we are navigating between the forces of triple-helix, tribes and territories, fixed typologies of researchers sometimes thinking strongly that we have found ourselves as researchers or managed to diminish our methodological dilemmas until we need to re-coordinate.

Following the practice-theoretical insights of Lave and Wenger (1991) we may argue that our professional identity not as static and permanent, but changing (to a degree) in and through social encounters and our participation in the scholarly world and beyond. Accordingly, through participation in a certain community (influenced by forces of discourse), we acquire certain valuations of scientific practice. However, these valuations are not immutable, as the environment and its demands are changing and communities interact with other communities. We have found ourselves becoming participants in the community of science through publishing, taking part in reviewing processes, giving expert statements to the media, lecturing and teaching, and presenting in seminars and conferences. However, currently the traditional activities have been augmented by applying for funding, the productization of research, boosting one's visibility, and the rapid production and report of results in easily digestible form. Such diversification of the academic practice, and accordingly, the diversification of experiencing and practicing academic identities has been suggested in several studies (e.g., Henkel, 2005; Smith, 2012, Ylijoki \& Ursin, 2013). For example, we are not only becoming researchers, but also (forced to become) academic entrepreneurs demanded to prove our productivity, effectivity, and existence in the knowledge economy. Nevertheless, not every publication is recognized and equally valued by the community as a source or example of good science, and these disagreements will probably prevail.

For Lave and Wenger (1991) the emphasis is not on the acquisition of skills and the transmission of knowledge from experts to novices - from professors (or books) to graduate students - but on the very process of participation and the notion of becoming a full participant. What we want to add is the (emerged demand of) endlessness of the process of becoming we have found through our introspection: the continuous movement - the navigation - inside theoretical frameworks, continuously altering trends of research, emerging new methods in relation to broader changes and forces that seek to define what type of research is significant. Be that as it may, the longer we have been wandering in the world of research, the more uncertain it seems that there is a "core" in the academia (or in the field of educational sciences) at all. Perhaps it is just another periphery towards which we are floating? For us it is easier to perceive the community of research as a dynamic rhizome including various quasi-communities than a stable structure with an identifiable core (Deleuze \& Guattari, 1987). In our minds tribes and territories have begun to hybridize generating new pathways, or new lines, within this rhizomatic understanding of the field of science. On the one hand, these ideas allow us to consider the many possibilities what scholarship can be; or the various possibilities of "becoming". And on the other, we can always be expected to learn more and produce more. Surprisingly, we find ourselves sharing our lunch with both postmodernism and neo-liberalism. This is an uneasy relationship.

In this article, we have attempted to think with different metaphors in order to situate ourselves in the field of science and understand our processes related to formulation of professional identity. We don't claim that these ideas could be generalized across scholarly contexts, even though we do think, in line with the practice-theoretical assumptions, that our thinking is in many ways socially embedded. Further research could investigate whether other emerging scholars would find our self-exploratory method useful. We see no reason why other methodological choices, such as surveys, interviews or documentary analyses, could not be utilized as well. However, the idea here has not been to provide generalizations about what scholarly life is, but instead to cast light 
on a postmodern path of self-exploration with the help of metaphors in order to illustrate the complexity of our "becoming". Further, instead of reducing the chaos into clearly bounded themes, we have attempted to portray our experiences of scholarly incoherence - that is, messiness and immaturity - as one core aspect describing our processes of becoming academics.

Through writing and thinking together, we have found that metaphors do stimulate the process of understanding. However, as we have seen, the simplifying nature of metaphors is also a dilemma as it is set against complex worlds where boundaries are shady. Thus, we do not offer these metaphors as solutions to challenges faced, but they have, perhaps, helped us to position ourselves, and thus, at least partially, to gain a hint of mastery in this messy and rhizomatic community of practice. In this regard, we find that exploration of metaphors could benefit also other young scholars across disciplines, as well as their supervisors in their processes of becoming.

\section{References}

Bacon, F., (1620/1863). Novum organum. Book one. Retrieved April 27, 2015, from http://www.constitution.org/bacon/nov_org.htm

Beaty, R. E., \& Silva, P. J. (2012). Metaphorically speaking: Cognitive abilities and the production of figurative language. Memory \& Cognition, 41(2), 255-267.

Becher, T., \& Trowler, P. R., (2001). Academic tribes and territories (2nd ed.). Milton Keynes: SRHE \& Open University Press.

Chang, H., Ngunjiri, F., \& Hernandez, K. A. C. (2010). Living autoethnography: Connecting life and research. Journal of Research Practice, 6(1), article E1. Retrieved May 5, 2015, from http://jrp.icaap.org/index.php/jrp/article/view/241/186

Chang, H., Ngunjiri, F., \& Hernandez, K. A. C. (2012). Collaborative autoethnography. Walnut Creek, CA: Left Coast Press.

Dauphinee, E. (2010). The ethics of autoethnography. Review of International Studies, 36(03), 799-818.

Deleuze, G., \& Guattari, F. (1987). A thousand plateaus: Capitalism and schizophrenia. Minneapolis: University of Minnesota Press.

Ellis, C. (2004). The ethnographic I: A methodological novel about autoethnography. Walnut Creek, CA: AltaMira Press.

Ellis, C. (2007). Telling secrets, revealing lives relational ethics in research with intimate others. Qualitative inquiry, 13(1), 3-29.

Ellis, C., Adams, T. E., \& Bochner, A. P. (2012). Autoethnography: An overview. Forum: Qualitative Social Research Sozialforschung, 12(1). Retrieved April 14, 2015, from http://www.qualitativeresearch.net/index.php/fqs/article/view/1589/3095

Etzkowitz, H., \& Leydesdorff, L. (Eds.) (1997). Universities and the global knowledge economy. A triplehelix of university-industry-government relations. London \& Washington: PInter.

Gallos, J. (1996). On becoming a scholar: One woman's journey. In P. J. Frost \& M. S. Taylor (Eds.). Rhythms of academic life: Personal accounts of careers in academia. (pp. 11-18). Thousand Oaks, CA: Sage.

Gallacher, L-A., \& Gallagher, M. (2008). Methodological immaturity in childhood research? Thinking through 'participatory methods'. Childhood, 15(4), 499-516.

Hakala, J. (2009). The future of the academic calling? Junior researchers in the entrepreneurial university. Journal of Higher Education, 57(2), 173-190.

Hemlin, S., Allwood C. M., \& Martin, B. R. (2008). Creative knowledge environments. Creativity Research Journal, 20(2), 196-210. 
Henkel, M. 2005. Academic identity and autonomy in a changing policy environment. Higher Education, $48($ nos. $1 / 2), 155-176$.

Hernandez, K. A. C., Ngunjiri, F. W., \& Chang, H. (2014). Exploiting the margins in higher education: A collaborative autoethnography of three foreign-born female faculty of color. International Journal of Qualitative Studies in Education, 28(5), 533-551.

Hernández, F., Sancho, J. M., Creus, A., \& Montané, A. (2010). Becoming university scholars: Inside professional autoethnographies. Journal of Research Practice, 6(1), article M7. Retrieved May 4, 2015, from http://jrp.icaap.org/index.php/jrp/article/view/204

Kouhia, A., \& Tammi, T. (2014). Akateemisen kapitalismin uusliberaali tutkijasubjekti kasvatustieteellisessä tohtorikoulutuksessa. [The neoliberal subject of academic capitalism within the doctoral education of educational sciences in Finland.] Kasvatus \& Aika, 8(2), 22-39.

Lakoff, G., \& Johnson, M. (1980). Metaphors we live by. Chicago, IL: University of Chicago Press.

Lave, J., \& Wenger, E. (1991). Situated learning: Legitimate peripheral participation. Cambridge: Cambridge University Press.

Pyhältö, K., Vekkaila, J., \& Keskinen, J. (2012). Exploring the fit between doctoral students' and supervisors' perceptions of resources and challenges vis-à-vis the doctoral journey. International Journal of Doctoral Studies, 7, 395-414. Retrieved from http://ijds.org/Volume7/IJDSv7p395-414Pyhalto383.pdf

Räsänen, K., \& Korpiaho, K. (2011). Supporting doctoral students in their professional identity projects. Studies in Continuing Education, 33(1), 19-31.

Sfard, A. (1998). On two metaphors for learning and the dangers of choosing just one. Educational Researcher, 27(2), 4-13.

Slaughter, S., \& Leslie, L. (1997). Academic capitalism. Politics, policies and the entrepreneurial university. Baltimore \& London: The John Hopkins University Press.

Smith, K. (2012). Fools, facilitators and flexians: Academic identities in marketised environments. Higher Education Quarterly, 66(2), 155-173.

Standing, G. (2011). The precariat: The new dangerous class. Bloomsbury Academic.

Sweetser, E., \& Fauconnier, G. (1996). Cognitive links and domains. In G. Fauconnier \& E. Sweetser (Eds.), Spaces, worlds and grammar (pp. 1-28). Chicago and London: The University of Chicago Press.

Thibodeau, P. H., \& Boroditsky, L. (2011). Metaphors we think with: The role of metaphor in reasoning. PLOS ONE, 6(2). Retrieved May 11, 2015, from http://www.plosone.org/article/info\%3Adoi\%2F10.1371\%2Fjournal.pone.0016782

Vekkaila, J., Pyhältö, K., \& Lonka, K. (2013). Experiences of disengagement-A study of doctoral students in the behavioral sciences. International Journal of Doctoral Studies, 8, 61-81. Retrieved from http://ijds.org/Volume8/IJDSv8p061-081Vekkaila0402.pdf

Ylijoki, O-H. \& Ursin, J. (2013). The construction of academic identity in the changes of Finnish higher education. Studies in Higher Education, 38(8), 1135-1149. 


\section{Biographies}

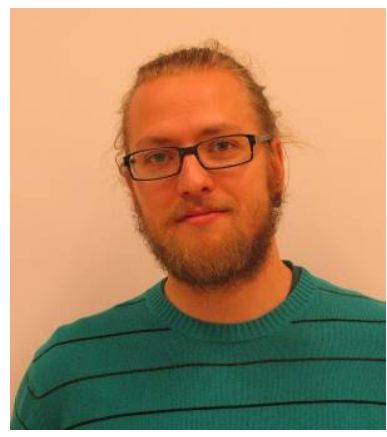

Tuure Tammi (M.Ed.) is currently finishing his $\mathrm{PhD}$ at University of Helsinki, Finland. Next to his dissertation project that discusses issues related to student participation, he has also engaged in projects exploring neoliberal governance in higher education, and reflexive methodologies.

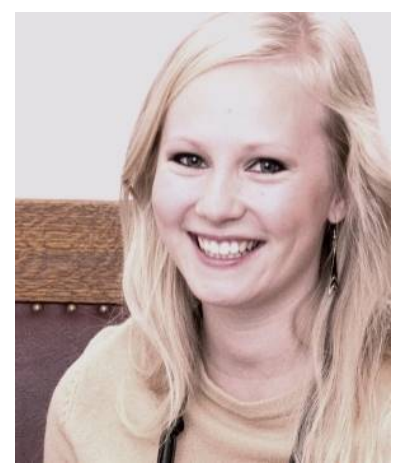

Anna Kouhia is a textile handcraft teacher and a $\mathrm{PhD}$ candidate in Craft Studies at University of Helsinki, Finland. Kouhia has been engaged in several collaborative writing projects, mostly discussing doctoral students' experiences, academic capitalism, and creative collaboration. Her PhD study examines the experiences of amateur textile craft making. 